\title{
Comparison of Agility and Dynamic Balance in Elderly Women with Endomorphic Mesomorph Somatotype with Presence or Absence of Metabolic Syndrome
}

\author{
Comparación de la Agilidad y Equilibrio Dinámico en Mujeres Adultas Mayores con Somatotipo \\ Mesomorfo Endomorfico y Presencia o Ausencia de Síndrome Metabólico \\ *,***Paulina Yesica Ochoa Martínez; *,** Javier Arturo Hall López; *,**Edgar Ismael Alarcón Meza; *Iván Rentería; \\ ${ }^{* * * * *}$ Ana María Miranda Botelho Teixeira; ${ }^{*}$ Lara Zazueta Humberto \& ${ }^{* *, * * *}$ Estélio Henrique Martin Dantas
}

OCHOA MARTÍNEZ, P. Y.; HALL LÓPEZ, J. A.; ALARCÓN MEZA, E.; RENTERÍA, I.; BOTELHO TEIXEIRA, A. M. M.; LARA ZAZUETA, H. \& MARTIN DANTAS, E. H. Comparison of agility and dynamic balance in elderly women with endomorphic mesomorph somatotype with presence or absence of metabolic syndrome. Int. J. Morphol., 30(2):637-642, 2012.

SUMMARY: Physical function declines in efficiency with advancing age, contributing to disability. Furthermore, metabolic syndrome is a common illness in elderly populations, somatotayping is a technique for description of the physique and can establish a relation with performance and pathology. The aim of this work was to compare the agility, dynamic balance in elderly women with endomorphic mesomorph somatotype with presence or absence of metabolic syndrome. A sample of 18 volunteers was obtained (age $66.5 \pm 4.7$ years old), all were elderly sedentary women. They were assessed whit anthropometric variables in accordance with ISAK protocol in order to determine Heath \& Carter somatotype; presence of metabolic syndrome they were evaluated according with the NCEP ATP-III, the agility and dynamic balance was assessed with the functional test Time Up and Go (TUGT). Mean of somatotype in subjects with absence or presence of metabolic syndrome was 6.2-7.9-0.2 and 6.5-8.7-0.1 respectively; Shapiro-Wilk test checked the normality of the distribution in the functional test Time Up and Go, in the group with absence or presence of metabolic syndrome, based on its normality distribution for the intergroup comparison, the Student t test was applied, the significance level, utilized was 95\% (P $\leq, 0.05)$ for the sample assessed without metabolic syndrome, the execution time of the functional test TUGT was better in spite of the same somatotype intergroup. The pathological components of metabolic syndrome can be related whit dysfunctional mobility in elderly women.

KEY WORDS: Somatotype; Elderly; Metabolic Syndrome; Agility; Dynamic Balance.

\section{INTRODUCTION}

The process of aging is characterized by a decrease in the physiological capacity, progressively declining functions of the organs and systems (Fulop et al., 2010), older adults presenting a natural progressive loss of physical capacities and a dysfunction of the musculoskeletal system by gradual changes in their body mass index (Rexhepi et al., 2011), as well as body composition, decreasing muscle mass and bone mineral density and increasing the body fat mass content (Rolland et al., 2009); These effects result in a unbalance of motricity, becoming more weak (Jang \& Van Remmen, 2010; Doubova et al., 2010; Blain et al., 2010, Fraga et al., 2011; Guzmán et al., 2011), predisposing the elderly to have lower functional autonomy in activities of daily living such as walking, climbing stairs, or rising from a chair without the help of a person or device (Molt et al., 2010; Reid et al., 2008; de Noronha et al., 2010).

Studies report that the decrease in agility and equilibrium is associated with the risk of falls (Rockwood et al., 2000), this being a high incidence factor at this stage of life (Formiga et al., 2008; Molt \& McAuley, 2010; McPhail et al., 2010), enhancing motor disability, which affects more than half of $60+$ year old people (Chevalier $e t$ al., 2008) predisposing these type of populations to be more fragile and increases dependence by losing their functional autonomy, being these causes the most common reason for isolate them into nursing homes (Vivanti et al., 2011).

\footnotetext{
School of Sports, Autonomous University of Baja California (UABC), Mexico.

** Postgraduate Stricto Sensu Euro-American Network of Human Kinetics (REMH).

**** Laboratory of Human Motricity Biosciences (LABIMH), Federal University of State of Rio de Janeiro, Brazil.

***** Faculty of Sports Science and Physical Education, University of Coimbra. Portugal.
} 
OCHOA MARTÍNEZ, P. Y.; HALL LÓPEZ, J. A.; ALARCóN MEZA, E.; RENTERÍA, I.; BOTELHO TEIXEIRA, A. M. M.; LARA ZAZUETA, H. \& MARTIN DANTAS, E. H. Comparison of agility and dynamic balance in elderly women with endomorphic mesomorph somatotype with presence or absence of metabolic syndrome. Int. J. Morphol., 30(2):637-642, 2012.

Heath \& Carter (1972) define the somatotype as a method that describes an individual's current body shape and composition, expressed in the quantification of three components (endomorphy, which expresses body fat content, mesomorphy is the development of skeletal muscle and ectomorphy is the linearity or thinness of the body) relative to height (Norton \& Olds, 1996). The assessment of somatotype in the field of medicine has been associated with the level of fitness, a variety of risk factors for health and the presence of chronic degenerative pathologies (Williams et al., 2000; Saitoglu et al., 2007; Martínez et al., 2008). The classification of endomorphic mesomorph somatotype is characterized by dominance in the mesomophy component and a tendency to endomorphy (Carter \& Heath, 1990).

Metabolic syndrome (MS) is a health complication that has been strongly associated whit the elder population (Bener et al., 2010), which is a disease of complex nature, consisting of five major clinical components: abdominal obesity, atherogenic dyslipidemia, elevated blood pressure and insulin resistance without glucose intolerance in potentially harmful combinations that significantly rise cardiovascular risk (Luk et al., 2008), various authors report straight associations of the MS with an endomorphic somatotype (Gordon et al., 1987; Koleva et al., 2002; Herrera et al., 2004; Kalichman et al., 2004; Buffa et al., 2007).

Elder adults show different rates of classification in their somatotypes (Buffa et al., 2005), furthermore physical characteristics modify the form of the body in general population (Kolpakov et al., 2009), as well as different classifications in physically active people compared with sedentary (Rodríguez et al., 2010). The aim of thise investigation was to compare the agility and dynamic balance in older adults with endomorphic mesomorph somatotype with presence or absence of metabolic syndrome.

\section{MATERIAL AND METHOD}

The study design was cross-sectional, descriptive and comparative of two groups with non probabilistic and convenience sampling. Subjects with interest of joining an aquatic stimulation program at the aquatic complex of the school of sports at the Autonomous University of Baja California were recruited. The sample consisted of 18

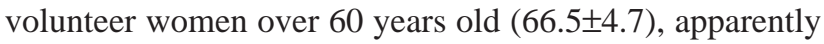
healthy who meet the following criteria: ambulation capacity, not have performed a systematical routine of exercise in the previous six months, a somatotype rated as endomorphic mesomorph, quantification of clinical and biochemical parameters by a medical and laboratory evaluation to assess the presence or absence of MS and evaluation of the agility and dynamic equilibrium by a functional test.

The total number of subjects was divided into two groups, one diagnosed with MS $(\mathrm{n}=8)$ and the other without MS ( $\mathrm{n}=10)$. All participants signed an informed consent (according with Helsinki declaration of 2008); the study was approved by the ethics committee of the School of Sports of the Autonomous University of Baja California. (n⿳⺈ 2011-1/01).

To determine the somatotype, the Heath \& Carter method was used; Anthropometric measurements were conducted by a level two antropometrist following the guidelines set by the International Society for Advancement of Kinanthropometry (ISAK) with a technical error of measurement less or equal to $1 \%$. The following measurements were taken: body weight $(\mathrm{cm})$, height $(\mathrm{cm})$, four skinfolds $(\mathrm{mm})$ triceps, sub scapular, supra spinal and medial calf, two circumferences $(\mathrm{cm})$ flexed arm, maximum calf, and two bone diameters $(\mathrm{cm})$ humeral and femur. The equipment used was a Seca 220 scale and stadiometer, and the Rosscraft Inc. Tomkit (Slimguide skinfold caliper, bone diameter vernier and Lufkin metal anthropometric tape).

A medical and laboratory evaluation assessed the clinical and biochemical parameters to evaluate the existence of MS using the guidelines of the National Cholesterol Educational Program Adult Treatment PanelIII (NCEP ATP-III). The blood pressure (BP) was obtained sitting at rest for 5 minutes by a sphygmomanometer (Omron hem-713c), umbilical abdominal circumference (UAC) was measured by a Lufkin metal anthropometric tape. Fasting venous blood was obtained to evaluate the biochemical variables of total cholesterol (TC), high density lipoprotein cholesterol (HDL-C) and triglycerides (TG). The values of TC and TG were analyzed using an enzymatic colorimetric method and HDL-C with a homogeneous enzymatic assay in which enzymes modified by Polyethylene Glycol (PEG) produce the separation in presence of magnesium and dextrin sulfates at the same time of analysis, the quantification was performed in a modular selective multichannel photometric auto analyzer P800 (Roche Diagnostics), and plasma blood glucose with an auto analyzer by the method of glucose oxidaseperoxidase (Beckman C5 Cincron, Bayer).

MS was diagnosed in older women who had three or more of the following criteria: abdominal obesity (UAC $>88 \mathrm{~cm}$ ), TG values $X \geq 150 \mathrm{mg}$.dl-1, HDL-C values $X$ $<50 \mathrm{mg}$. $\mathrm{dl}^{-1}$; BP values $\geq 130 / 85 \mathrm{mmHg}$, or taking antihypertensive treatment, and plasma fasting glucose levels $110 \geq \mathrm{mg} \cdot \mathrm{d}^{\mathrm{l}-1}$ (Luk et al., 2008). 
OCHOA MARTÍNEZ, P. Y.; HALl LÓPEZ, J. A.; ALARCóN MEZA, E.; RENTERÍA, I.; BOTELHO TEIXEIRA, A. M. M.; LARA ZAZUETA, H. \& MARTIN DANTAS, E. H.

Comparison of agility and dynamic balance in elderly women with endomorphic mesomorph somatotype with presence or absence of metabolic syndrome. Int. J. Morphol., 30(2):637-642, 2012.

Agility and dynamic balance were assessed using the Timed up and go Test (TUGT), whose implementation began with the subject seated in the middle of a chair $(43.18 \mathrm{~cm})$ with both hands on the thighs and their feet on the ground, set slightly one below the another, a signal was given to start the test, the test started when the subject raised from the chair, walk as fast as possible around a cone placed 8 feet $(2.4 \mathrm{~m})$ in front of the chair and sit back, the timer started as soon as the subject moved and stopped when the person sat down again, the test was administered twice, and the shortest time recorded was used (Rikli \& Jones, 2001).

The variables were analyzed by descriptive and inferential statistics (SPSS 17.0), the somatotype was processed by the computer program Nolds LifeSize Sports Scientific (1998) setting out the components in a somatochart.

\section{RESULTS}

The values of the variables are shown in mean, standard deviation and range. Table I shows the general and anthropometric characteristics, and somatotype components are referred in Table II, Table III reports the clinical and biochemical parameters of metabolic syndrome, and the results of the test of agility and dynamic balance in both groups.

The spatial distribution of somatotype and dispersion (SDD) and attitudinal distances (SAD) of both groups with respect to their average value can be seen in Figures 1 and 2. The SDD values $X$ for both groups were $6.6 \pm 3.4$ and 5.2 \pm 2.5 somatotype units, for the SAD $X$ were $3.4 \pm 2.0$ and $2.7 \pm 1.5$ somatotype units respectively.

Table I. Mean, standard deviation and range of general anthropometric characteristics in both groups ( $\mathrm{n}=18)$.

\begin{tabular}{|c|c|c|c|c|}
\hline \multirow[b]{3}{*}{ Basics } & \multicolumn{2}{|c|}{ with $M S(n=8)$} & \multicolumn{2}{|c|}{ without $M S(n=10)$} \\
\hline & $\mathrm{X} \pm \mathrm{DS}$ & Range & $\mathrm{X} \pm \mathrm{DS}$ & Range \\
\hline & & & & \\
\hline Age (years) & $68.0 \pm 4.9$ & $62-75$ & $65.4 \pm 4.5$ & $60-73$ \\
\hline Body weight mass (kg) & $77.7 \pm 8.9$ & $64.9-90$ & $72 \pm 13.4$ & $49.3-92.1$ \\
\hline Height $(\mathrm{cm})$ & $151.4 \pm 3.8$ & $146-156$ & $154.5 \pm 7.2$ & $146.6-167$ \\
\hline $\operatorname{IMC}\left(\mathrm{kg} / \mathrm{m}^{2}\right)$ & $34.2 \pm 5.1$ & $29.5-42.5$ & $30.5 \pm 4.9$ & $22.9-41.9$ \\
\hline \multicolumn{5}{|l|}{ Skinfolds (mm) } \\
\hline Ttriceps & $20.4 \pm 5.5$ & $11.5-26.5$ & $19.8 \pm 4.2$ & $11.5-25.2$ \\
\hline Sub scapular & $22.1 \pm 5.7$ & $13.2-30.2$ & $21.9 \pm 9.8$ & $13.5-49$ \\
\hline Supra spinal & $20.3 \pm 3.8$ & $15.2-26.0$ & $18.1 \pm 6.4$ & $8.2-31.5$ \\
\hline Medial calf & $26.5 \pm 10.5$ & $12.5-46.7$ & $18.5 \pm 5.7$ & $7.9-25.5$ \\
\hline \multicolumn{5}{|l|}{ Circumferences (cm) } \\
\hline Flexed arm & $35.8 \pm 4.1$ & $31.1-42.2$ & $34 \pm 3.8$ & $28-38$ \\
\hline Maximum calf & $37.2 \pm 6.0$ & $31.5-48.9$ & $35.5 \pm 3.9$ & $29.5-42$ \\
\hline \multicolumn{5}{|l|}{ Bone diameters (cm) } \\
\hline Humeral & $6.9 \pm .3$ & $6.4-7.4$ & $7.1 \pm .6$ & $6.1-7.9$ \\
\hline Femur & $10.4 \pm .7$ & $9.3-11.6$ & $9.9 \pm .6$ & $9-11$ \\
\hline
\end{tabular}

Table II. Mean, standard deviation and range of somatotype components in both groups $(\mathrm{n}=18)$.

\begin{tabular}{lcccc}
\hline & \multicolumn{2}{c}{ with $\boldsymbol{M S}(\mathbf{n = 8})$} & \multicolumn{2}{c}{ without $\boldsymbol{M S}(\boldsymbol{n}=\mathbf{1 0})$} \\
& $\mathbf{X} \pm \mathbf{D S}$ & Range & $\mathbf{X} \pm \mathbf{D S}$ & Range \\
\hline Endomorphy & $6.5 \pm 1$ & $4.5-8$ & $6.2 \pm 1.3$ & $4.6-9.4$ \\
Mesomorphy & $8.7 \pm 2$ & $7-12$ & $7.9 \pm 1.5$ & $5.6-10.6$ \\
Ectomorphy & $0.1 \pm .0$ & $0.1-0.1$ & $0.2 \pm 0.2$ & $0.1-0.9$ \\
SDD & $6.6 \pm 3.4$ & $3.3-12$ & $5.2 \pm 2.5$ & $1.4-10$ \\
SAD & $3.4 \pm 2.0$ & $1.6-6.8$ & $2.7 \pm 1.5$ & $.73-6.24$ \\
X Coordinate & $-6.4 \pm 1$ & $-7.9--4.4$ & $-6 \pm 1.4$ & $-9.3--3.7$ \\
Y Coordinate & $10.8 \pm 3.3$ & $7.5-16$ & $9.4 \pm 2.2$ & $5.7-12.4$ \\
\hline
\end{tabular}


OCHOA MARTÍNEZ, P. Y.; HALL LÓPEZ, J. A.; ALARCóN MEZA, E.; RENTERÍA, I.; BOTELHO TEIXEIRA, A. M. M.; LARA ZAZUETA, H. \& MARTIN DANTAS, E. H. Comparison of agility and dynamic balance in elderly women with endomorphic mesomorph somatotype with presence or absence of metabolic syndrome. Int. J. Morphol., 30(2):637-642, 2012.

Table III. Mean, standard deviation and range of clinical and biochemical parameters of metabolic syndrome, and the results of the test of agility and dynamic balance, in both groups $(n=18)$.

\begin{tabular}{|c|c|c|c|c|}
\hline & \multicolumn{2}{|c|}{ with $M S(n=8)$} & \multicolumn{2}{|c|}{ without $M S(n=10)$} \\
\hline & $\mathrm{X} \pm \mathrm{DS}$ & Range & $\mathrm{X} \pm \mathrm{DS}$ & Range \\
\hline Umbilical abdominal & $107.3 \pm 10.8$ & $90.4-126.5$ & $98.7 \pm 10.6$ & $82.5-117.3$ \\
\hline Sistolic blood pressure (BPS) & $143.6 \pm 12.7$ & $128-166$ & $121 \pm 18.3$ & $97-158$ \\
\hline Diastolic blood pressure (BPD) & $77.5 \pm 5.5$ & $69-85$ & $72.5 \pm 15.2$ & $47-92$ \\
\hline High density lipoprotein & $40.7 \pm 7.4$ & $31.5-52.6$ & $46 \pm 7.98$ & $31.5-52.6$ \\
\hline Triglycerides (TG) mg.dl-1 & $149.2 \pm 55.4$ & $95-263$ & $126.4 \pm 26.1$ & $94-190$ \\
\hline Glucose mg.dl-1 & $133.5 \pm 98.5$ & $61-367$ & $82.2 \pm 11.9$ & $67-100$ \\
\hline Timed up and go Test TUGT & $8.4 \pm 1.5$ & $6.9-11.58$ & $6.2 \pm 1$ & $4.8-8.3$ \\
\hline
\end{tabular}

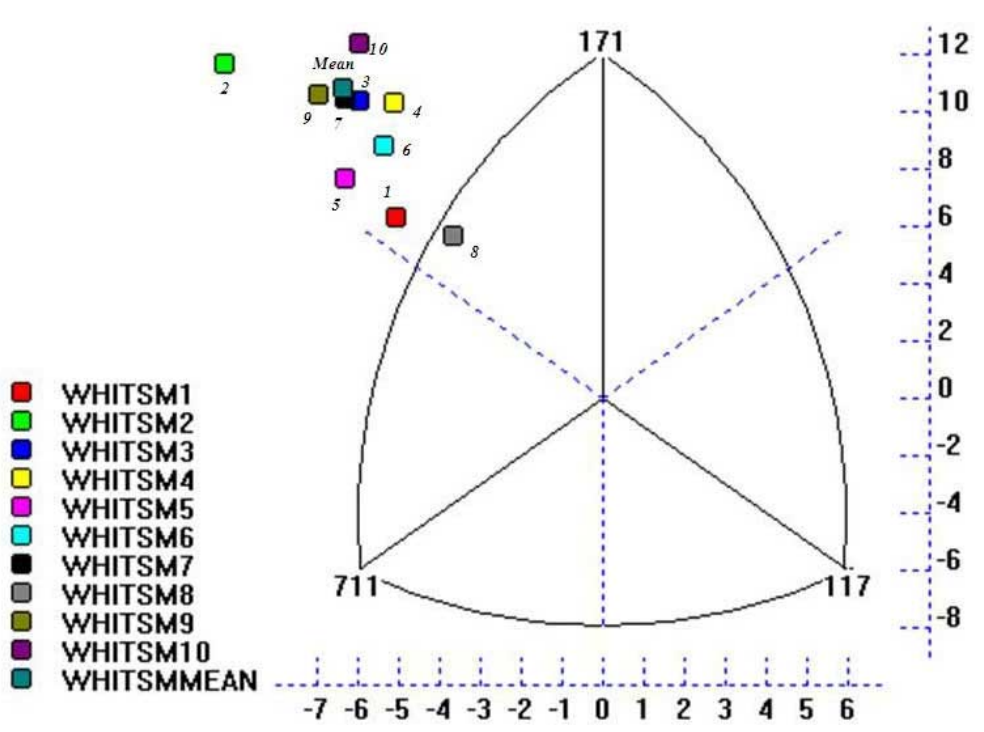

Fig. 1. Spatial distribution of somatotype in the group with MS ( $n=8)$.

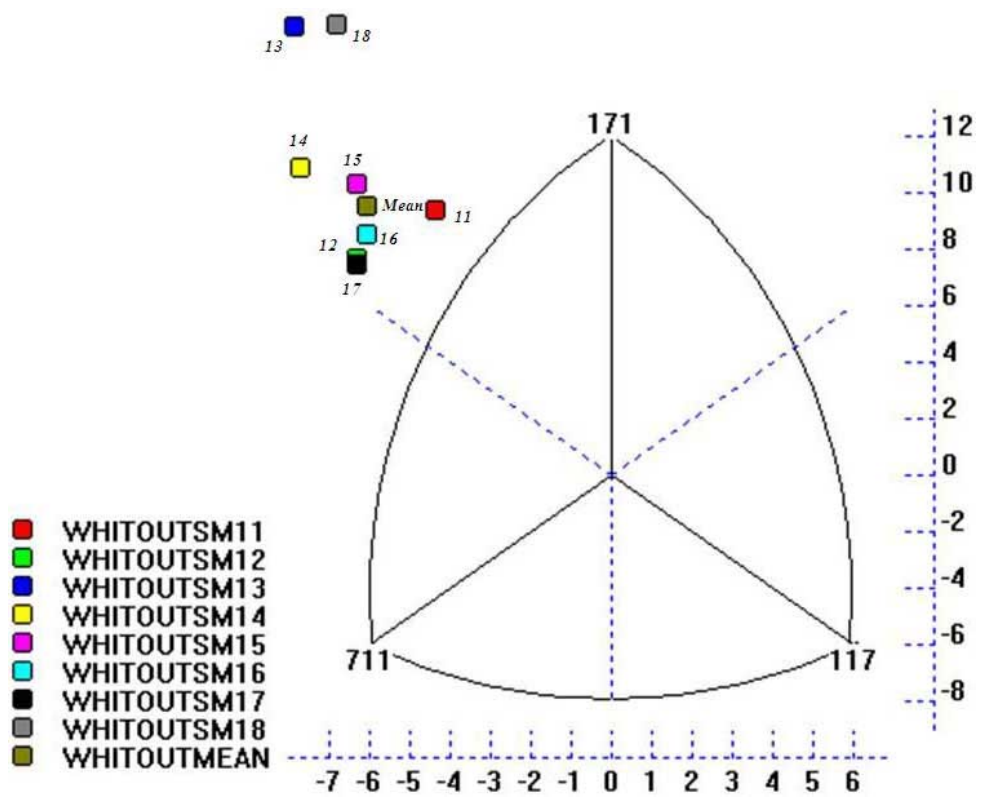

Fig. 2. Spatial distribution of somatotype in the group without MS ( $\mathrm{n}=10)$.
The Shapiro-Wilk test of normality was used to establish homogeneity in the test of agility and dynamic balance between the groups with presence or absence of MS, the values $\mathrm{X}$ were (.148 and .755 respectively) $\mathrm{p}>0.05$, to analyze the comparison of the TUGT between groups the t-test of Student was used, the group without MS had a significantly better agility and dynamic balance $(p=.005)$. There were no significant differences between the other study variables.

\section{DISCUSION}

In the present investigation, the values $\mathrm{X}$ of clinical and biochemical parameters, and somatotype did not differ between groups. However, the group with absence of MS showed better agility and dynamic equilibrium, indicating a possible lower risk of falling and greater functional autonomy. The components of the MS have been linked to somatotype, studies show that a dominance in the endomorphic component tends to be directly related to abdominal obesity (Koleva et al., 2002), elevated blood pressure (Herrera et al., 2004; Kalichman et al., 2004), high fasting glucose values (Buffa et al., 2007), low HDL-C and elevated TG (Gordon et al., 1987).

The anthropometric and somatotype characteristics of both study groups were similar, showing a dominance of the mesomorphic component and a trend towards endomorphy, which differs from data published by Buffa et al. (2007) which indicate that in older women with type 2 diabetes mellitus, the endomorphic component is predominant, which is recognized as a major factor of prevalence for the presence of chronic non communicable diseases. This particular somatotype 
OCHOA MARTÍNEZ, P. Y.; HALL LÓPEZ, J. A.; ALARCóN MEZA, E.; RENTERÍA, I.; BOTELHO TEIXEIRA, A. M. M.; LARA ZAZUETA, H. \& MARTIN DANTAS, E. H.

Comparison of agility and dynamic balance in elderly women with endomorphic mesomorph somatotype with presence or absence of metabolic syndrome. Int. J. Morphol., 30(2):637-642, 2012.

of the group with MS in this study does not concur with those found in the literature (Carter \& Heath, 1990; Gordon et al., 1987), however, the average value of endomorphy in both groups is considered high, according to the classification given by the authors of this morphological indicator, although it could be suggested that the inconsistency of these results is attributable to no differences in the body composition between groups.

Bouchard et al. (2011) showed in a population of metabolically healthy obese women and others with some type of co-morbidities, that functional capacity is better in the group without co-morbidities, attributing a lower risk of disability. Another study in population with low functional autonomy, central adiposity in the body and the presence of MS (Rush et al., 2011) concluded that high levels of fat combined with the presence of MS decreased functional autonomy. The data found in our study is similar to those found in a study in older adults associated with low functional capacity and presence of MS (Roriz-Cruz et al., 2007) because the agility and dynamic balance were significantly better in older adults with absence of SM despite having a similar somatotype, so this variable in the sample tested is not a good indicator to identify older adults prone to falling risk with low functional autonomy through their walking ability.

To conclude, it is possible that the pathological components of the metabolic syndrome may be associated with a loss of functional autonomy in these groups of older women, and the somatotype did not serve as a good indicator to identify MS and risk factors of falling in this type of elderly women's population.

ACKNOWLEDGMENTS: For support and funding granted through the UABC PIFI program, $16^{\text {th }}$ internal research call of the Autonomus University of Baja California (UABC) and the Consortium of Mexican Universities CUMex.

OCHOA MARTÍNEZ, P. Y.; HALL LÓPEZ, J. A.; ALARCÓN MEZA, E.; RENTERÍA, I.; BOTELHO TEIXEIRA, A. M. M.; LARA ZAZUETA, H. \& MARTIN DANTAS, E. H. Comparación de la agilidad y equilibrio dinámico en mujeres adultas mayores con somatotipo mesomorfo endomorfico y presencia o ausencia de síndrome metabólico Int. J. Morphol., 30(2):637-642, 2012

RESUMEN: Conforme la edad progresa, se presenta una pérdida en la funcionalidad física del ser humano, contribuyendo al deterioro de su autonomía funcional, además el síndrome metabólico (SM) es un padecimiento común en poblaciones de adultos mayores. El somatotipo es una técnica utilizada para describir la forma del físico en diferentes tipos de poblaciones que puede establecer una relación con su rendimiento físico y patologías. El objetivo de este trabajo fue comparar la agilidad y equilibrio dinámico en adultas mayores con un somatotipo mesomorfo-endomorfico con presencia o ausencia de SM. Fue reclutada una muestra de 18 mujeres adultas mayores sedentarias (edad promedio de $66.5 \pm 4.7$ años). Las variables antropométricas fueron valoradas utilizando los lineamientos establecidos por ISAK y se determinó el índice morfológico del somatotipo por el procedimiento de Heath \& Carter. La presencia de SM fue evaluada de acuerdo al
NCEP ATP-III, la agilidad y equilibrio dinámico fue medido mediante el test funcional de Timed up and go (TUGT). La media del somatotipo en las sujetos con ausencia y presencia de SM fue de 6.2-7.9-0.2 y 6.5-8.7-0.1 respectivamente; el test de Shapiro-Wilk fue utilizado para observar la normalidad de la distribución de los datos en el test de funcionalidad (TUGT)de ambos grupos, ya comprobada la normalidad de los datos, se aplicó la prueba t de Student con el nivel de significancia 95\% ( $\mathrm{P} \leq, 0.05)$, comprobando que el grupo con ausencia de SM presentó una mejor agilidad y equilibrio dinámico. Es posible que los componentes patológicos del SM puedan estar relacionados con una pérdida de autonomía funcional en mujeres adultas mayores.

PALABRAS CLAVE: Somatotipo; Ancianos; Síndrome Metabólico; Agilidad; Equilibrio Dinámico.

\section{REFERENCES}

Bener, A.; Mohammad, A. G.; Ismail, A. N.; Zirie, M.; Abdullatef, W. K. \& Al-Hamaq, A. O. Gender and age-related differences in patients with the metabolic syndrome in a highly endogamous population. Bosn. J. Basic. Med. Sci., 10(3):210-7, 2010.

Blain, H.; Carriere, I.; Sourial, N.; Berard, C.; Favier, F.; Colvez, A. \& Bergman, H. Balance and walking speed predict subsequent 8year mortality independently of current and intermediate events in well-functioning women aged 75 years and older. J. Nutr. Health. Aging., 14(7):595-600, 2010.

Bouchard, D. R.; Langlois, M. F.; Brochu, M.; Dionne, I. J. \& Baillargeon, J. P. Metabolically healthy obese women and functional capacity. Metab. Syndr. Relat. Disord., 9(3):225-9, 2011.

Buffa, R.; Succa, V.; Garau, D.; Marini, E. \& Floris, G. Variations of somatotype in elderly Sardinians. Am. J. Hum. Biol., 17(4):40311, 2005.

Buffa, R.; Floris, G.; Putzu, P. F.; Carboni, L. \& Marini, E. Somatotype in elderly type 2 diabetes patients. Coll. Antropol., 31(3):733-7, 2007.

Carter, J. E. L. \& Heath, B. H. Somatotyping-Development and Applications. Cambridge: Cambridge University Press. 1990.

Chevalier, S.; Saoud, F.; Gray-Donald, K. \& Morais, J. A. The physical functional capacity of frail elderly persons undergoing ambulatory rehabilitation is related to their nutritional status. J. Nutr. Health. Aging., 12(10):721-6, 2008.

de Noronha, D. F.; de Souza R. G.; Giani, T. S.; Bacellar, S.; Escobar, T.; Stoutenberg, M. \& Dantas, E. H. Correlation between static balance and functional autonomy in elderly women. Arch. Gerontol. Geriatr., 52(1):111-4, 2011.

Doubova, S. V.; Pérez-Cuevas, R.; Espinosa-Alarcón, P. \& FloresHernández, S. Social network types and functional dependency in older adults in Mexico. BMC. Public. Health., 27(10):104, 2010.

Fraga, M. J.; Cader, S. A.; Ferreira, M. A.; Giani, T. S. \& Dantas, E. H. Aerobic resistance, functional autonomy and quality of life (QoL) of elderly women impacted by a recreation and walking program. Arch. Gerontol. Geriatr., 52(1):40-3, 2011. 
OCHOA MARTÍNEZ, P. Y.; HALL LÓPEZ, J. A.; ALARCóN MEZA, E.; RENTERÍA, I.; BOTELHO TEIXEIRA, A. M. M.; LARA ZAZUETA, H. \& MARTIN DANTAS, E. H.

Comparison of agility and dynamic balance in elderly women with endomorphic mesomorph somatotype with presence or absence of metabolic syndrome. Int. J. Morphol., 30(2):637-642, 2012.

Formiga, F.; Lopez-Soto, A.; Duaso, E.; Chivite, D.; Ruiz, D.; PerezCastejon, J. M.; Navarro, M. \& Pujol, R. Characteristics of falls producing hip fractures in nonagenarians. J. Nutr. Health. Aging., 12(9):664-7, 2008

Fulop, T.; Larbi, A.; Witkowski, J. M.; McElhaney, J.; Loeb, M.; Mitnitski, A. \& Pawelec, G. Aging, frailty and age-related diseases. Biogerontology., 11(5):547-63, 2010

Gordon, E.; Tobias, P. V.; Mendelsohn, D.; Seftel, H. \& Howson, A. The relationship between somatotype and serum lipids in male and female young adults. Hum. Biol., 59(3):459-65, 1987.

Guzmán, R. A.; Salazar H. A.; Cea, A.; Melián, H. P.; Cordier, B. \& Silvestre, R. A. Correlación entre el puntaje obtenido en la prueba "Timed up and go" y momentos articulares del miembro inferior registrados durante la transferencia de sedente a bípedo en adultos mayores con antecedentes de caídas frecuentes. Int. J. Morphol., 29(2):521-525, 2011.

Herrera, H.; Rebato, E.; Hernández, R.; Hernández-Valera. \& Alfonso-Sánchez, M. A. Relationship between somatotype and blood pressure in a group of institutionalized Venezuelan elders. Gerontology, 50(4):223-9, 2004.

Jang, Y. C. \& Van Remmen, H. Age-associated alterations of neuromuscular junction. Exp. Gerontol., 46(2-3):193-8, 2010.

Kalichman, L.; Livshits, G. \& Kobyliansky, E. Association between somatotypes and blood pressure in an adult Chuvasha population. Ann. Hum. Biol., 31(4):466-76, 2004.

Koleva, M.; Nacheva, A. \& Boev, M. Somatotype and disease prevalence in adults. Rev. Environ. Health., 17(1):65-84, 2002.

Kolpakov, V. V.; Bespalova, T. V.; Bragin, A. V.; Lebedeva, K. A.; Tomilova, E. A. \& Vesnina, T. A. The concept of typological variability of physiological individuality: II. Somatotype heterogeneity of population groups differing in habitual physical activity. Fiziol. Cheloveka., 35(1):75-83, 2009.

Luk, A. O.; Ma, R. C.; So, W. Y.; Yang, X. L.; Kong, A. P.; Ozaki, R.; Ko, G. T., Chow, C. C.; Cockram, C. S.; Chan, J. C. \& Tong, P. C. The NCEP-ATPIII but not the IDF criteria for the metabolic syndrome identify Type 2 diabetic patients at increased risk of chronic kidney disease. Diabet. Med., 25(12):1419-25, 2008.

Martínez, C.; Silva, H.; Collipal, E. \& Carrasco S. V. Descripción del Somatotipo e IMC en una Muestra de Adolescentes de Colegios Municipalizados de la Ciudad de Temuco - Chile. Int. J. Morphol., 26(3):653-657, 2008.

McPhail, S.; Beller, E. \& Haines, T. Physical function and healthrelated quality of life of older adults undergoing hospital rehabilitation: how strong is the association?. J. Am. Geriatr. Soc., 58(12):2435-7, 2010.

Motl, R. W. \& McAuley, E. Physical activity, disability, and quality of life in older adults. Phys. Med. Rehabil. Clin. N. Am., 21(2):299308,2010
Norton, K. \& Olds, T. Antropometrica. Marrickville, Sidney, Ed. Southwood Press, 1996.

Reid, K. F.; Naumova, E. N.; Carabello, R. J.; Phillips, E. M. \& Fielding, R. A. Lower extremity muscle mass predicts functional performance in mobility-limited elders. J. Nutr. Health. Aging., 12(7):4938, 2008.

Rexhepi, A.; Brestovci, B. \& Krasniqi, A. Physical Characteristics at Different Ages. Int. J. Morphol., 29(1):105-111, 2011.

Rikli, R. E. \& Jones, C. J. Senior Fitness Test Manual. Champaign, IL: Human Kinetics. 2001.

Rockwood, K.; Awalt, E.; Carver, D. \& Macknightm, C. Feasibility and measurement properties of the functional reach and the timed up and go tests in the Canadian Study of Health and Aging. $J$. Gerontol. A. Biol. Sc.i Med. Sci.; 55(2):70-3, 2000.

Rodríguez, F.; Almagià, A.; Yuing, T.; Binvignat.; O. \& Lizana, P. Composición Corporal y Somatotipo Referencial de Sujetos Físicamente Activos. Int. J. Morphol., 28(4):1159-1165, 2010.

Rolland. Y.; Lauwers-Cances,V.; Cristini,; C.; Abellan,; van Kan, G.; Janssen, I.; Morley, J. E. \& Vellas, B. Difficulties with physical function associated with obesity, sarcopenia, and sarcopenic-obesity in community-dwelling elderly women: the EPIDOS (EPIDemiologie de l'OSteoporose) Study. Am. J. Clin. Nutr., 89(6):1895-900, 2009.

Roriz-Cruz, M.; Rosset, I.; Wada, T.; Sakagami, T.; Ishine, M.; RorizFilho, J. S.; Cruz, T. R.; Rodrigues, R. P.; Resmini, I.; Sudoh, S.; Wakatsuki, Y.; Nakagawa, M.; Souza, A.C.; Kita, T. \& Matsubayashi, K. Stroke-independent association between metabolic syndrome and functional dependence, depression, and low quality of life in elderly community-dwelling Brazilian people. J. Am. Geriatr. Soc., 55(3):374-82, 2007.

Rush, E. C.; Crook. N. \& Simmons, D. Relationships between a walk test, body size and metabolic risk among a New Zealand $\mathrm{Ma}^{-}$ori community. Ann. Hum. Biol., 37(1):117-27, 2010.

Saitoglu, M.; Ardicoglu, O.; Ozgocmen, S.; Kamanli, A. \& Kaya, A. Osteoporosis risk factors and association with somatotypes in males. Arch. Med. Res. 38(7):746-51, 2007.

Vivanti, A.; Ward, N. \& Haines, T. Nutritional status and associations with falls, balance, mobility and functionality during hospital admission. J. Nutr. Health. Aging., 15(5):388-91, 2011.

Williams, S. R.; Goodfellow, J.; Davies, B.; Bell, W.; McDowell, I. \& Jones, E. Somatotype and angiographically determined atherosclerotic coronary artery disease in men. Am. J. Hum. Biol., 12(1):128-138, 2000.

\section{Correspondence to:}

Dr. Javier Arturo Hall López

Autonomous University of Baja California (UABC)

MEXICO

Email: javierhall@uabc.edu.mx

Received: 25-10-2011

Accepted: 03-02-2012 